\title{
Nitrogen-fixation and phosphate-solubilization bacteria isolated from alluvial and latosol soil paddy field
}

\author{
IKHWANI ${ }^{1,2, v}$, NONON SARIBANON ${ }^{2, v v}$, TATANG MITRA SETIA ${ }^{2}$, ERNY YUNIARTI $^{3}$, JUMAKIR $^{4}$ \\ ${ }^{1}$ Indonesian Center for Food Crops Research and Development. Jl. Merdeka 147, Bogor 16111, West Java, Indonesia. Tel. +62-25-18334089/8331718, \\ Fax.+62-51-8312755. •email: isunihardi21@ gmail.com \\ ${ }^{2}$ Program of Conservation Biology, Department of Biology, Universitas Nasional. Jl. Sawo Manila No. 61, West Jakarta 12520, Jakarta, Indonesia \\ ${ }^{3}$ Indonesian Soil Research Institute. Jl. Tentara No. 12, Bogor 16111, West Java, Indonesia. "“email: nonsa.enviro@ gmail.com \\ ${ }^{4}$ Assesment Institute of Agricultural Technology of Jambi. Jl. Samarinda, Jambi City 36129, Jambi, Indonesia
}

Manuscript received: 4 May 2021. Revision accepted: 11 October 2021.

\begin{abstract}
Ikhwani, Saribanon N, Setia TM, Yuniarti E, Jumakir. 2021. Nitrogen-fixation and phosphate-solubilization bacteria isolated from alluvial and latosol soil paddy field. Biodiversitas 22: 4722-4730. This study aims to isolate, select and identify molecular characterization of bacteria from alluvial and latosol soil paddy field. This study has been conducted from February-June 2020 in the Soil Biology Laboratory, ICALRRD, Bogor. Alluvial and latosol soil samples were selected from Pusakanagara and Muara experimental gardens, Muara district. The result showed that bacteria growth in $\mathrm{N}$-free media was higher from latosol soil as compared to alluvial soil. The higher nitrogenase activity isolates, could form ethylene gas concentration 1.1.E $+09 \mu \mathrm{mol} / \mathrm{mL} / \mathrm{hours}, 1.7 . \mathrm{E}+09$ $\mu \mathrm{mol} / \mathrm{mL} /$ hours and 1.3.E $+09 \mu \mathrm{mol} / \mathrm{mL} /$ hours from alluvial 6, latosol 4, and latosol 9. Three isolates have great PSB performances,

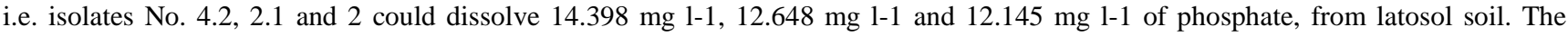
highest $\mathrm{N}$-fixing and solubilization capacity identified by molecular characterization i.e latosol 4, 4.2 and alluvial 7.1, alluvial-1.11. The phylogeny analyzed the presence of bacterial isolates in two distinct groups. Latosol 3.1 and latosol 4.2 isolates clustered in the same as the genus Lysinibacillus bacteria. The Alluvial 7.1 bacterial isolate showed similarities by Fictibacillus sp. and alluvial 1.2 isolate showed similarities by the genus Bacillus sp.
\end{abstract}

Keywords: Bacterial identified, molecular, nitrogenase activity, nitrogen fixation

\section{INTRODUCTION}

Soil plays a major role in determining the plant growth due to its function as a growing medium, so the increase of plant production is often inseparable from soil productivity itself. Cultural practice such as the addition of Nitrogen (N), Phosphorus (P) and Potassium (K) fertilizers, ameliorants and organic matter is proven to increase plant productivity in paddy fields (Sukristiyonubowo et al. 2012). Despite its advantages, the excessive application of inorganic fertilizers plays a role in soil fertility and crop production; they are cost-effective, environmentally friendly and act as a complement to agricultural sustainability (Khorso and Yousef 2012). In addition, the inappropriate usage of inorganic fertilizers can pollute the nearby air and ground water, for example the occurrence of eutrophication or the rapid growth of algae in water body (Youssef and Eissa 2014).

A paddy field is one of the locations that is mostly exposed to excessive inorganic fertilizers. Two important and essential macronutrients highlighted in the present study are nitrogen $(\mathrm{N})$ and phosphate $(\mathrm{P})$. In terms of $\mathrm{N}$, the excessive application may decline the production cost efficiency due to the high potency of $\mathrm{N}$ loss that occurred through leaching, ammonia volatilization and denitrification (Cameron et al. 2013). Furthermore, it is important to improve biological nitrogen fixation on rice fields (Ma et al. 2019). In terms of P, it is sometimes found in excessive amounts in a paddy field as an impact of continuous fertilization. Phosphate-soluble bacteria are bacteria that can dissolve insoluble phosphate into soluble, both derived from the soil and from fertilizers, so that it can be absorbed by plants (Alfiah et al. 2016). In acidic soil, the $\mathrm{P}$ is bound to iron $(\mathrm{Fe})$ and aluminum $(\mathrm{Al})$ forming the Fe-P and Al-P complex, while in alkaline soil, $\mathrm{P}$ is bound to calcium (Ca) form $\mathrm{Ca}_{3}\left(\mathrm{PO}_{4}\right)_{2}$ complex (Sukristiyonubowo et al. 2012). The portion of undissolved $\mathrm{P}$ in certain soil varies in range between $95-99 \%$ (Ranjan et al. 2013). However, 95-99\% of naturally occurring phosphates are bound, insoluble and precipitated (Alori et al. 2017). Plants generally absorb phosphate in the form of ions $\mathrm{H}_{2} \mathrm{PO}_{4}$ and $\mathrm{HPO}_{4}$ (Bhattacharyya and Jha 2012).

The $\mathrm{N}$ fixation mechanism is reported through the process of synthesis of nitrogenase, an oxygen labile enzyme that catalyzes molecular nitrogen from the atmosphere to be ammonia that can be used by plants (Bhat et al. 2015). A different mechanism is observed during the solubilization of undissolved $\mathrm{P}$ that is done through the production of organic acids, siderophores, protons, hydroxyl ions, $\mathrm{CO}_{2}$, P-excretion enzyme, releasing $\mathrm{P}$ during the process of substrate degradation (Sharma et al. 2013; Murthi and Lisnawita 2015). Currently, beneficial microbes such as biological nitrogen fixation (BNF) and $\mathrm{P}$ solubilizing bacteria (PSB) are widely used in the agroecosystem to improve soil and plant productivity (Cameron et al. 2013), in case NFB and PSB induces plant growth 
directly and increases the uptake and availability of nutrients through nitrogen fixation, increasing mineral solubility, mineralization of organic and production of phytohormones (Bhardwaj et al. 2014). The characterization of NFB and PSB may differ in response to different soil types. Nitrogen fixing bacteria (NFB) and phosphate solubilizing bacteria (PSB) are widely for microbiological fertilizers in the soil to plant production (Natzke et al. 2018). Different soil types are followed by different soil characters, leading to different soil biological diversity. Therefore, the objectives of this study are to isolate, select and identify molecular characterization of biological nitrogen fixation and the solubilization of insoluble inorganic phosphates bacteria, and define their role in the nitrogen fixation and solubilizing ability of the isolated bacteria from alluvial and latosol paddy soil types.

\section{MATERIALS AND METHODS}

\section{Study area}

This study was conducted from February to June 2020 at the Laboratory of Soil Biology, Indonesian Center for Agricultural Land Resources Research and Development (ICALRRD), Bogor, Indonesia. Soil samples were collected from rainfed paddy field at the experimental garden of Pusakanagara (Subang District) and Muara (Bogor City), West Java, Indonesia to obtain alluvial and latosol soil types. The soil samples were located at $23.1 \mathrm{~m}$ above sea level (asl.) (coordinates: 6'25'42'4's and $\left.107^{\circ} 89^{\prime} 69,9^{\prime \prime} \mathrm{E}\right)$, while Muara experimental garden was located at $291 \mathrm{~m}$ asl. (coordinates: 6036'54 $\mathrm{S}$ and $106^{\circ} 47^{\prime} 29^{\prime \prime} 85^{\circ} \mathrm{E}$ ) respectively (Figure 1).

Soil samples were analyzed to bacteria isolated at the soil depth up to $20 \mathrm{~cm}$ below soil surface, in five spots for every location. The composite soil sample was taken to soil laboratory ICALRRD to selection and isolation of microbial (Kesaulya et al. 2015). The other single sample was used for the chemical characterization of the soil and observed prior to texture, $\mathrm{pH}$, organic $\mathrm{C}, \mathrm{N}$ total, available $\mathrm{P}$ was tested through 2 solvents, i.e. $\mathrm{HCl} 25 \%$ and Olsen., cation exchange capacity (CEC), K-dd, Ca-dd, Mg-dd, Na$\mathrm{dd}, \mathrm{Al}^{+} \mathrm{dd}$, reduced $\mathrm{Fe}$ and fractionated $\mathrm{P}(\mathrm{Al}, \mathrm{Ca}$ and $\mathrm{Fe})$. In addition, some soil was prepared for a bacterial population abundance test, after which it was refined and tested for all mentioned analysis, and was held in the Soil Biology Laboratory, ICALRRD.

\section{Bacterial isolation, and selection}

Isolation and selection bacterial used alluvial and latosol soil samples from which $1 \mathrm{~g}$ was taken and shaken with $9 \mathrm{~mL}$ of $0.85 \% \mathrm{NaCl}$ for 30 minutes to obtain of $\mathrm{N}$ fixing. Graded dilutions from $10^{-1}$ to $10^{-6}$ were carried out using $1 \mathrm{~mL}$ of the mixture. The first test tube contained 9 $\mathrm{mL}$ of sterile water. Shaking was consistent in composition using a vortex. The procedure was repeated until $10^{-6}$ (the 6 th test tube). The cultured using a triangle spreader rod on the Burk's medium contained $20 \mathrm{~g}$ of sucrose, $0.64 \mathrm{~g}$ of $\mathrm{K}_{2} \mathrm{HPO}_{4}, 0.16 \mathrm{~g}$ of $\mathrm{KH}_{2} \mathrm{PO}_{4}, 0.20 \mathrm{~g}$ of $\mathrm{MgSO}_{4} .7 \mathrm{H}_{2} \mathrm{O} 0.20 \mathrm{~g}$ of $\mathrm{NaCl}, 0.05 \mathrm{~g}$ of $\mathrm{CaSO}_{4} .2 \mathrm{H}_{2} \mathrm{O}, 5 \mathrm{~mL}$ of $\mathrm{Na}_{2} \mathrm{MoO}_{4} \cdot 2 \mathrm{H}_{2} \mathrm{O}$
(0.05\%), $5 \mathrm{~mL}$ of $\mathrm{FeSO}_{4} .7 \mathrm{H}_{2} \mathrm{O}(0.3 \%), 21 \mathrm{~g}$ of gel (Ding et al. 2005) and $1000 \mathrm{~mL}$ of aquades and incubated for 24 hours at room temperature (Hartono and Jumadi 2014). Nitrogenase activity was measured using the gas chromatography method. Acetylene as an analog of the $\mathrm{N}_{2}$ substrate was injected into the Porapak Q column with hydrogen and nitrogen carrier gas. The acetylene wavelength at the retention time was noted at $2 \mathrm{~h}$ of incubation. The gas chromatograph was conditioned for \pm 3 hours prior to sample injection. The initial, injector, detector and final temperatures of $\mathrm{GC}$ instrument were $100^{\circ} \mathrm{C}, 150^{\circ} \mathrm{C}, 200^{\circ} \mathrm{C}$ and $100^{\circ} \mathrm{C}$ respectively. Carrier gases such as nitrogen, hydrogen and air were used at gas flow $40 \mathrm{psi}, 1.5 \mathrm{kgf} \mathrm{cm}^{-2}$ and 0.5 at $\mathrm{kgf} \mathrm{cm}^{-2}$, respectively (Hawkes 2001). The standard curve of ethylene was made from five concentrations of ethylene, i.e. 0.2, 0.4, 0.6, 0.8 and $1.0 \mu \mathrm{g} \mathrm{mL}^{-1}$. Bacterial isolates were grown on semisolid nitrogen free broth for 3-4 days. About $1 \mathrm{~mL}$ of the produced gas inside the tube was replaced with acetylene gas using a microsyringe; it was then incubated for 1 hour. Afterward, $1 \mathrm{~mL}$ of gas in the headspace of the test tube was taken to measure the concentration of ethylene $\left(\mathrm{C}_{2} \mathrm{H}_{4}\right)$ formed in the gas chromatography instrument. A quantitative analysis of nitrogenase activity was done after the acetylene reduction assay (ARA) method. The nitrogenase activity was calculated by following the formula below:

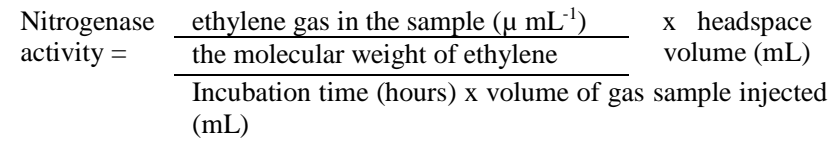

The soil samples to isolation, selection and identification $\mathrm{P}$ solubilizing used much as 10 grams, with a known water content; it was put in glass that contained 90 $\mathrm{mL}$ sterile distilled water and then stirred for 1 hour at 120 rpm. A total of $1 \mathrm{~mL}$ soil extract was put into a test tube that contained $9 \mathrm{~mL}$ sterile distilled water and then homogenized with the vortex. Afterward, $1 \mathrm{~mL}$ was transferred to the next container until the dilution formed $10^{-2}$ to $10^{-7}$. As much as $0.1 \mathrm{~mL}$ was taken from the prepared dilution and transferred into a sterile petri dish and then poured in Pikovskaya selective media that composed of $5 \mathrm{~g} \mathrm{Ca}_{3}\left(\mathrm{PO}_{4}\right)_{3} \mathrm{OH}$ as $\mathrm{P}$ solvent, $10 \mathrm{~g}$ glucose, $0.2 \mathrm{~g} \mathrm{NaCl}, 0.2 \mathrm{~g} \mathrm{KCL}, 0.1 \mathrm{~g} \mathrm{MgSO}_{4} .7 \mathrm{H}_{2} \mathrm{O}, 0.5 \mathrm{~g}$ $\left(\mathrm{NH}_{4}\right)_{2} \mathrm{SO}_{4}, 0.5 \mathrm{~g}$ yeast extract, $0.0025 \mathrm{~g} \mathrm{MnSO}_{4}, 0.0025 \mathrm{~g}$ $\mathrm{FeSO}_{4}, 1 \mathrm{~g} \mathrm{FeO}_{4}$ and $1 \mathrm{~g} \mathrm{Al}-\mathrm{P}$ that dissolved in 1 liter of $\mathrm{H}_{2} \mathrm{O}(\mathrm{pH} \mathrm{P}=6.8, \mathrm{pH} \mathrm{Fe}$ and $\mathrm{Al}=5.6)$, and then incubated for 3-7 days at $28{ }^{\circ} \mathrm{C}$. Colonies with a clear area, called holozone were observed, calculated and then purified. The purified BPF colonies were placed in a petri dish containing sterile solid Pikovskaya media to test its performance to dissolve $\mathrm{P}$. The phosphate solubilizing bacterial performance index was qualitatively measured by following. Sane and Mehta (2015) as stated below.

Phosphate solubilizing bacterial performance index $(\mathrm{SI})=$ Colony diameter + holozone diameter Colony diameter 
The capable of solubilizing calcium phosphate of isolated performed of clear zone (holozone) around bacterial colonies. In addition, a quantitative test of BPF performance was also done using the spectrophotometry approach. Bacterial isolates were inoculated into liquid Pikovskaya media and incubated for 15 days. After that, the culture solution was filtered with Whatman no.1 paper to obtain $20 \mathrm{~mL}$ of supernatant. Furthermore, a total of 13 $\mathrm{mL}$ of filtrate was placed in a centrifuge tube and centrifuged for 15 minutes at $1000 \mathrm{rpm}$. The supernatant was piped as much s $5 \mathrm{~mL}$, centrifuged and transferred into a test tube. The $\mathrm{P}$ dye reagent $1 \mathrm{~mL}$ of concentrated was added to $1 \mathrm{~mL}$ of $\mathrm{KH}_{2} \mathrm{PO}_{4}\left(0.295 \mathrm{~g} 100 \mathrm{~mL}^{-1}\right)$, used to prepare a standard solution of $1000 \mathrm{ppm}$, then diluted to obtain a concentration of 0 ppm, 2 ppm, 4 ppm, 6 ppm, 8 $\mathrm{ppm}$ and $10 \mathrm{ppm}$. The standard solution and samples were mixed with concentrated reagent $\mathrm{P}$ and incubated for 30 minutes. Subsequently, the phosphate dissolution was measured using a UV-VIS spectrophotometer at wavelength of $693 \mathrm{~nm}$.

\section{$\mathbf{N}$ fixing and $\mathbf{P}$ solubilizing bacteria identification}

The potential and highest $\mathrm{N}$ fixation ability and $\mathrm{P}$ solubilizing bacteria isolate were identified, i.e. latosol 3.1, alluvial 1.2., latosol 4.2 and alluvial 7.1. The PCR analysis was carried out in a Molecular Biology Laboratory of ICABIOGRAD, Indonesian Agency for Agricultural Research and Development (IAARD), Bogor, West Java, in March 2021. Genomic DNA was extracted using GF-1 Bacterial DNA Extraction Kit (Vivantis, Malaysia). A total of $1 \mathrm{~mL}$ of bacterial suspension (liquid culture) that had been grown on LB media was 24 hours old in the exponential phase and transferred to a $2 \mathrm{~mL}$ microtube.

\section{DNA amplification and sequencing}

For molecular characterization, the strains that excelled in the later experiments was the highest $\mathrm{N}$-fixing and solubilization capacity of sources. Phosphate solubilizing was selected and submitted for $16 \mathrm{~S}$ rDNA gene sequencing. Identification of bacterial species was carried out on four bacterial isolates whose DNA was amplified in a total reaction of $40 \mu \mathrm{l}$ containing $10 \mathrm{mg}$ of $2 \mu \mathrm{l}$ of template DNA; 2x MyTaq HS (Bioline, UK) as much as 20 $\mu \mathrm{l}$ and Forward and Reverse primers with a concentration of $10 \mu \mathrm{M}$, each being $2 \mu \mathrm{l}$, and ddH2O was sterile. The primers used came from the 16SRNA gene fragment, e.g. the PSL (16S2-F) primer (5'-AGGATTAGATACCCTG GTAGTCCA-3') and XB4 (16S2-R) (5'GTGTGTACAAGGCCCGGGAAC-3'). Amplification was carried out on a PCR T1 Thermocycler machine (Biometra, Germany) with a PCR profile as follows: initial denaturation was carried out at $95{ }^{\circ} \mathrm{C}$ for 5 minutes, followed by 35 cycles of a denaturation process at $94{ }^{\circ} \mathrm{C}$ for 30 seconds, annealing (primary attachment stage) at temperature $55^{\circ} \mathrm{C}$ for 1 minute and extension (base extension) at $72^{\circ} \mathrm{C}$ for 1 minute.

\section{Data analysis}

The results of sequencing from each isolate were analyzed for homology using the Basic Local Alignment Search Tool (BLAST) program on the National Center for Biotechnology Information/NCBI database site (http://www.ncbi.nlm.nih.gov/). The homology results sequences that have the highest level of genetic similarity are selected, which will also be used as references in the preparation of phylogenetic trees. Phylogenetic tree construction was carried out using the Neighborhood Joining method with 1000 bootstraps on the Mega 10 software.

\section{RESULTS AND DISCUSSION}

\section{Alluvial and latosol soil characteristics}

Table 1 showed that the texture of alluvial and latosol soil was dominated by clay, i.e. $72 \%$ and $65 \%$, respectively. The sand fraction had the smallest soil portion, i.e. $2 \%$ in alluvial and $6 \%$ in latosol. The actual $\mathrm{pH}$ $\left(\mathrm{pH} \mathrm{H}_{2} \mathrm{O}\right.$ ) of alluvial was higher than latosol and so was the potential $\mathrm{pH}$. The organic $\mathrm{C}$ content of two observed soils was categorized as low due to being below $2 \%$. The $\mathrm{N}$ total was $0.14 \%$ and $0.18 \%$ in alluvial and latosol. The $\mathrm{P}$ content

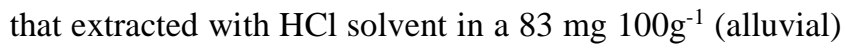

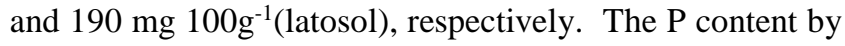
Olsen extracted $31 \mathrm{ppm}$ (alluvial) and $50 \mathrm{ppm}$ (latosol), respectively. Both results showed that alluvial had a lower $\mathrm{P}$ than latosol. Conversely, alluvial had a higher cation exchange capacity (CEC) shown than latosol.

Table 1. Chemical attributes of alluvial and latosol paddy field soils' samples

\begin{tabular}{|c|c|c|c|c|c|}
\hline Soil characteristics & Alluvial & Latosol & Soil characteristics & Alluvial & Latosol \\
\hline Sand (\%) & 2 & 6 & $\mathrm{~K}_{2} \mathrm{O} \mathrm{HCl} 25 \%\left({\left.\mathrm{mg} 100 \mathrm{~g}^{-1}\right)}\right.$ & 35 & 12 \\
\hline Dust (\%) & 26 & 29 & $\mathrm{P}_{2} \mathrm{O}_{5}(\mathrm{ppm})$ Olsen (ppm) & 31 & 50 \\
\hline Clay $(\%)$ & 72 & 65 & $\mathrm{~K}_{2} \mathrm{O}(\mathrm{ppm})$ Morgan (ppm) & 245 & 116 \\
\hline $\mathrm{pH} \mathrm{H}_{2} \mathrm{O}$ & 6.2 & 5.6 & Ca-dd $\left(\mathrm{cmol}(+) \mathrm{kg}^{-1}\right)$ & 15.53 & 7.55 \\
\hline $\mathrm{pH} \mathrm{KCl}$ & 5.0 & 4.5 & $\operatorname{Mg}-\mathrm{dd}\left(\mathrm{cmol}(+) \mathrm{kg}^{-1}\right)$ & 7.58 & 2.26 \\
\hline $\mathrm{Al}-\mathrm{dd}\left(\mathrm{cmol}(+) \mathrm{kg}^{-1}\right)$ & 0.0 & 0.0 & $\mathrm{~K}-\mathrm{dd}\left(\operatorname{cmol}(+) \mathrm{kg}^{-1}\right)$ & 0.41 & 0.23 \\
\hline $\mathrm{H}-\mathrm{dd}\left(\mathrm{cmol}(+) \mathrm{kg}^{-1}\right)$ & 0.31 & 0.14 & Na-dd $\left(\operatorname{cmol}(+) \mathrm{kg}^{-1}\right)$ & 0.91 & 0.31 \\
\hline C-organic $(\%)$ & 1.37 & 1.85 & Total & 24.43 & 10.35 \\
\hline $\mathrm{N}$ total $(\%)$ & 0.14 & 0.18 & Cation exchange capacity $\left(\mathrm{cmol}(+) \mathrm{kg}^{-1}\right)$ & 29.58 & 15.02 \\
\hline $\mathrm{C} / \mathrm{N}$ ratio & 10 & 10 & Base saturation $(\%)$ & 83 & 69 \\
\hline $\mathrm{P}_{2} \mathrm{O}_{5} \mathrm{HCl} 25 \%\left(\mathrm{mg} 100 \mathrm{~g}^{-1}\right)$ & 83 & 190 & & & \\
\hline
\end{tabular}

Note: Alluvial and latosol soil types were collected from Pusakanagara and Muara experimental garden, respectively. 
Table 2. The performance of nitrogen-fixing bacteria and phosphate solubilizing bacteria from latosol and alluvial paddy field in several growing media

\begin{tabular}{llll}
\hline \multirow{2}{*}{ Beneficial bacteria } & \multicolumn{1}{c}{ Growing media } & \multicolumn{2}{c}{ Number of bacteria $\left(\right.$ CFU $\left.\mathbf{~ g}^{-1}\right)$} \\
\cline { 3 - 4 } & & \multicolumn{1}{c}{ Alluvial } \\
\hline Nitrogen fixing bacteria & N free & $2.29 \times 106$ & $2.11 \times 105$ \\
& NFB semi solid & $4.3 \times 103\left(\mathrm{MPN} \mathrm{g}^{-1}\right)$ & $9.2 \times 103\left(\mathrm{MPN} \mathrm{g}^{-1}\right)$ \\
Phosphate solubilizing bacteria & & & $1.10 \times 106$ \\
& $\mathrm{P}-\mathrm{Ca}$ & $3.79 \times 105$ & $9.70 \times 105$ \\
& $\mathrm{P}-\mathrm{Al}$ & $3.86 \times 105$ & $1.05 \times 106$ \\
& $\mathrm{P}-\mathrm{Rp}$ & $1.30 \times 106$ & $2.08 \times 105$ \\
\hline
\end{tabular}

Note: $\mathrm{N}$ free: nitrogen free media, NFB semi solid: nitrogen-fixing bacteria, semi solid media, P-Ca: Pikovskaya enriched with calcium, P-Al: Pikovskaya enriched with aluminum, P-Rp: Pikovskaya rock phosphate, P-Fe: Pikovskaya enriched with Fe. Alluvial and latosol soil types were collected from Pusakanagara and Muara experimental garden, respectively

Table 3. The content of $\mathrm{P}$ in the form of 4 phosphate fractions both in alluvial and latosol paddy field

\begin{tabular}{cccccc}
\hline \multirow{2}{*}{ Soil type } & \multicolumn{3}{c}{ Fractionation (mg/l ) } \\
\cline { 2 - 5 } & Cl-P & Al-P & Fe-P & 134.4 & Ca-P \\
Alluvial & 9.0 & 38.2 & 253.3 & 13.5 \\
Latosol & 5.3 & 42.3 & & \\
\hline
\end{tabular}

Note: Cl-P: chlorine phosphate, Al-P: aluminum phosphate, Fe-P: iron phosphate, Ca-P: calcium phosphate. Alluvial and latosol soil types were collected from Pusakanagara and Muara experimental garden, respectively

An observed variable like $\mathrm{C} / \mathrm{N}$ ratio could be used to monitor the $\mathrm{C}$ and $\mathrm{N}$ content simultaneously at soil sample. The $\mathrm{N}$ in soil could be used either by plant or microbes, so that it can cause $\mathrm{N}$ usage competition. The addition of an inappropriate organic fertilizer could reduce the availability of $\mathrm{N}$ for the plant (leading to $\mathrm{N}$ deficiency), since soil microbes actively use that nutrient to growth. Organic matter is an important key to maintain soil productivity, because it could be a stabilizer for soil aggregates (physical improvement), a source of plant nutrients (chemical improvement) and a suitable place for microbial growth (biological improvement). In addition to organic matter, soil $\mathrm{pH}$ was also an important observed variable since it indicated the availability of plant nutrients and also toxic elements. The high $\mathrm{P}$ solubilization was achieved at high $\mathrm{pH}$ (Yu et al. (2011). However, the decrease in $\mathrm{pH}$ is not always comparable by $\mathrm{P}$ solubilization (Behera et al. 2014). The metabolic processes and physiochemical reactions involve photosynthesis, transformation electron (energy transfer), signal transduction, macromolecular biosynthesis and respiration involving phosphorus as the main element (Khan et al. 2010).

\section{$\mathrm{N}$-fixing and $\mathbf{P}$ solubilizing bacteria performance}

The highest contained $\mathrm{N}$-fixing bacteria soil isolates were $2.29 \times 10^{6} \mathrm{CFU} \mathrm{g}^{-1}$ and $4.3 \times 10^{3} \mathrm{MPN} \mathrm{g}^{-1}$ was observed from latosol soil and $2.11 \times 10^{5} \mathrm{CFU} \mathrm{g}^{-1}$ and $9.2 \mathrm{x}$ $10^{3} \mathrm{MPN}^{-1}$ from alluvial type soil. The highest $\mathrm{P}$ solubilizing bacteria was observed in latosol soil isolate growth on solid Pikovskaya rock phosphate (P-Rp) media, i.e $1.30 \times 10^{6}$ cells $\mathrm{g}^{-1}$ followed by alluvial soil isolate on $\mathrm{P}$ Ca, i.e. $1.10 \times 10^{6}$ cells $\mathrm{g}^{-1}$. Meanwhile, the lowest PSB was noted in latosol isolate growth on the P-Fe medium, i.e. $1.75 \times 10^{4}$. The variation of PSB was $10^{4}-10^{6}$ in latosol and $10^{5}-10^{6}$ in alluvial. That difference might be related to the variation of environmental factors, such as soil $\mathrm{pH}$ and land elevation. Latosol isolate was obtained from the paddy field located at $291 \mathrm{~m}$ asl and had a soil $\mathrm{pH}$ ranging from 4.5-5.6 (acidic), while alluvial isolate was derived from land with lower altitude, i.e. $23.1 \mathrm{~m}$ asl and higher $\mathrm{pH}$ (neutral) in range of 5.0-6.20 (Table 2). The altitude, soil $\mathrm{pH}$ and different microbial habitats could inhibit the growth of PSB population (Sanjotha et al. 2011).

Table 3 showed that the $\mathrm{P}$ fraction in the form of Fe-P was the most dominant, followed by Al-P, Ca-P and Cl-P as the less dominant, either in latosol or alluvial. The p-Fe growing media of beneficial bacteria at Table 2 showed the lowest abundance $\left(1.75 \times 10^{4}\right.$ cell $\left.\mathrm{g}^{-1}\right)$ from latosol was associated with the highest $\mathrm{Fe}-\mathrm{P}$ fraction in latosol soil (253.3 ppm). It implied that the $\mathrm{P}$ availability in plants was low (Sharma et al. 2013). P-Fe could be more dominant in soil depending upon the climate. In acidic soil, $\mathrm{P}$ would react to $\mathrm{Al}$ and $\mathrm{Fe}$ to form $\mathrm{Fe}-\mathrm{P}$ and $\mathrm{Al}-\mathrm{P}$ that were difficult to dissolve and unavailable to absorb leading to $\mathrm{P}$ deficiency. $\mathrm{P}$ deficiency could be the main limitation for plant productivity growth in latosol. The low $\mathrm{pH}$ caused the high availability of toxic elements, such as $\mathrm{Al}$ and $\mathrm{Fe}$ that could bind $\mathrm{P}$, leading to unavailability for the plant (Kesaulya et al. 2015).

In total, there were 18 isolates both from alluvial and latosol that tested for its qualitative nitrogenase activity. In alluvial isolate group, the highest nitrogenase activity was observed in alluvial 6 isolate for about $1.1 \times 10^{9} \mu \mathrm{mol} \mathrm{mL}$ ${ }^{1}$ hours $^{-1}$, while the lowest result was found in alluvial 7 and 9 isolates for about $6.9 \times 10^{7} \mu \mathrm{mol} \mathrm{mL} \mathrm{mL}^{-1}$ hours ${ }^{-1}$. In latosol isolate group, the highest nitrogenase activity was observed in Latosol 4 isolate for about $1.7 \times 10^{9} \mu \mathrm{mol} \mathrm{mL} \mathrm{m}^{-1}$ hours ${ }^{1}$ and then followed by Latosol 9 isolate with nitrogenase activity for about $1.3 \times 10^{9} \mathrm{~mL}^{-1}$ hours ${ }^{-1}$, while the lowest result was observed in $1.7 \times 10^{8} \mathrm{~mL}^{-1}$ hours ${ }^{-1}$. Compared to alluvial, latosol soil isolate contained a higher nitrogenase activity. 
Table 4. The qualitative nitrogenase activity of several soil isolates obtained from latosol and alluvial paddy fields

\begin{tabular}{|c|c|c|c|c|c|}
\hline \multicolumn{3}{|c|}{ Alluvial } & \multicolumn{3}{|c|}{ Latosol } \\
\hline Isolate code & FEC & NA & Isolate code & FEC & NA \\
\hline & $(\mu \mathrm{g} / \mathrm{mL})$ & $(\mu \mathrm{mol} / \mathrm{mL}) /{ }^{1}$ hours $^{-1}$ & & $(\mu \mathrm{g} / \mathrm{mL})$ & $(\mu \mathrm{mol} / \mathrm{mL}) /^{1}$ hours $^{-1}$ \\
\hline Alluvial 1 & 0.04 & $2.6 . e+08$ & Latosol 1 & 0.05 & 3.0.E +08 \\
\hline Alluvial 2 & 0.11 & 7.1.e + 08 & Latosol 2 & 0.03 & 1.7.E + 08 \\
\hline Alluvial 3 & 0.11 & 6.8.e + 08 & Latosol 3 & 0.05 & 3.1.E + 08 \\
\hline Alluvial 4 & 0.02 & 1.1.e +08 & Latosol 4 & 0.27 & 1.7.E + 09 \\
\hline Alluvial 5 & 0.04 & 2.6.e +08 & Latosol 5 & 0.03 & 2.1.E + 08 \\
\hline Alluvial 6 & 0.18 & 1.1.e + 09 & Latosol 6 & 0.03 & 1.8. $\mathrm{E}+08$ \\
\hline Alluvial 7 & 0.01 & 6.9.e + 07 & Latosol 7 & 0.06 & 3.6.E + 08 \\
\hline Alluvial 8 & 0.01 & 7.2.e + 07 & Latosol 8 & 0.08 & 4.9. $E+08$ \\
\hline Alluvial 9 & 0.01 & $6.9 . e+07$ & Latosol 9 & 0.21 & 1.3.E + 09 \\
\hline
\end{tabular}

Note: FEC: formed ethylene gas concentration, NA: nitrogenase activity. alluvial and latosol soil type were collected from Pusakanagara and Muara experimental garden, respectively

Table 5. Qualitative Phosphate solubility index of several isolates from alluvial and latosol paddy field in two growing media, i.e. $\mathrm{Rp}$ and $\mathrm{Ca}$

\begin{tabular}{lccc}
\hline Growing media & Soil type & $\begin{array}{c}\text { Isolate } \\
\text { code }\end{array}$ & $\begin{array}{c}\text { Phosphate solubility } \\
\text { index (SI) }\end{array}$ \\
\hline $\mathrm{Ca}$ & Alluvial & 3.1 & 2.67 \\
& Latosol & 2.1 & 3.00 \\
& & 2.2 & 3.25 \\
& & 2.3 & 2.73 \\
& & 2.4 & 2.50 \\
$\mathrm{Rp}$ & & 2.5 & 2.80 \\
& & 3.1 & 3.22 \\
& Alluvial & 2.1 & 2.36 \\
& & 4.3 & 2.11 \\
& & 4.4 & 2.50 \\
& & 5.1 & 2.12 \\
& & 7.1 & 2.80 \\
& & 7.2 & 2.80 \\
& & 7.3 & 2.70 \\
& & 3.1 & 2.06 \\
& & 4.1 & 2.14 \\
& & 4.2 & 2.33 \\
\hline
\end{tabular}

Table 6. Quantitative Phosphate solubility index of several isolates from alluvial and latosol paddy field in two growing media, i.e. Rp and $\mathrm{Ca}$

\begin{tabular}{llccc}
\hline Media & $\begin{array}{l}\text { Soil } \\
\text { type }\end{array}$ & Isolate & $\begin{array}{l}\text { P } \\
\text { solubility } \\
\text { index }(\mathbf{m g} \\
\left.\mathbf{l}^{-\mathbf{1}}\right)\end{array}$ & $\begin{array}{l}\text { Daily } \\
\text { solubility } \\
\left(\boldsymbol{\mu g} \mathbf{~ m L}^{-\mathbf{1}} \mathbf{d a y}^{-\mathbf{1}}\right)\end{array}$ \\
\hline $\mathrm{Rp}$ & alluvial & 7.2 & 6,426 & $1.29 \times 10^{3}$ \\
& & 7.1 & 9,863 & $1.97 \times 10^{3}$ \\
& latosol & 4.2 & 14,396 & $2.88 \times 10^{3}$ \\
$\mathrm{Ca}$ & alluvial & 3.1 & 8,826 & $1.77 \times 10^{3}$ \\
& latosol & 2.1 & 12,648 & $2.53 \times 10^{3}$ \\
& & 2.2 & 12,145 & $2.43 \times 10^{3}$ \\
& & & & \\
& & 3.1 & 9,626 & $1.93 \times 10^{3}$ \\
\hline
\end{tabular}

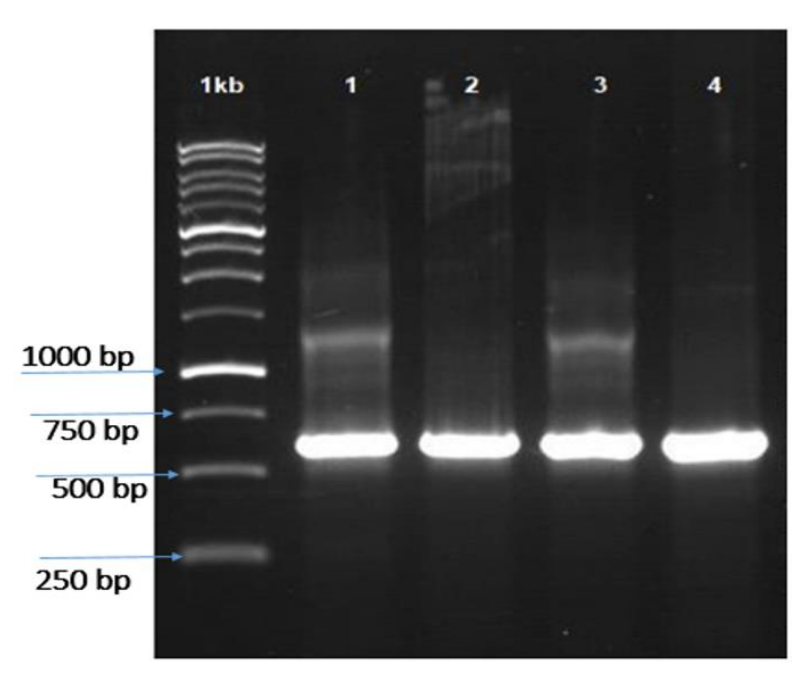

Figure 2. The results of the electrophoresis of PCR products for bacterial isolates on $1 \%$ agarose gel

In $\mathrm{Ca}_{3}\left(\mathrm{PO}_{4}\right)$ media, the alluvial soil contained only one isolate of $\mathrm{P}$ solubilizing, i.e. isolate 3.1 , with the $\mathrm{P}$ solubility index for about 2.67 and it was categorized as the high category. In opposite, there were 6 isolates found in latosol soil, i.e. $2.1,2.2,2.3,2.4,2.5$, and 3.1 with the $\mathrm{P}$ solubility index ranged from 2.50 to 3.25 . In alluvial soil with Rp media, there were 7 phosphate solubility isolates, i.e. isolate $2.1,4.3,4.4,5.1,7.1,7.2$, and 7.3 with the highest $\mathrm{P}$ solubility index of 2.80 from isolates 7.1 and 7.2. There were 3 latosol soil isolates, i.e. isolate 3.1, 4.1, and 4.2 with the highest $\mathrm{P}$ solubility index of 2.33 from isolate 4.2 (Table 5).

The $\mathrm{P}$ solubilizing activity was measured based on the clear zone formed in the media. The diameter of the clear zone indicated the activity of $\mathrm{P}$ solubilizing bacteria. The diameter of clear zone lower than $1 \mathrm{~cm}$ was considered as low activity, while diameter in between $1-2 \mathrm{~cm}$ was considered moderate activity. A diameter of more than 2 $\mathrm{cm}$ was considered a good activity (Baig et al. 2010). The larger the clear zone formed, the higher $\mathrm{P}$ solubility index, and the better the isolates' ability to dissolve $\mathrm{Ca}_{3}\left(\mathrm{PO}_{4}\right)_{2}$ (Paul and Sinha. 2013). Solubilizing P using solid 
medium (holozone indication) was less accurate than the measurement of $\mathrm{P}$ dissolved in liquid media. However, the results would be more accurate if the two measurements were correlated (Baig et al. 2010). The higher the enzyme activity of PSB, the larger the clear zone which was formed. The clear zone was formed due to the solubilizing of the undissolved P by PSB (Situmorang et al. 2015). Therefore, the colony PSB was alteration around to be a clear zone due to decline of $\mathrm{pH}$ in the turbidity medium (Paul and Sinha 2013).

Analysis of $\mathrm{P}$ solubilizing activity using a spectrophotometer at wavelength of $693 \mathrm{~nm}$, showed that there were three isolates with a high activity to dissolve $\mathrm{P}$, i.e. isolate $4.2,2.1$ and 2.2 with daily $\mathrm{P}$ solubility index about $2.88 \times 10^{3} \mu \mathrm{g} \mathrm{mL}^{-1}$ day $^{-1}, 2.53 \times 10^{3} \mu \mathrm{g} \mathrm{mL}^{-1}$ day $^{-1}$ and $2.43 \times 10^{3} \mu \mathrm{g} \mathrm{mL}^{-1} \mathrm{day}^{-1}$, respectively (Table 6). The lowest daily PSB performance was observed in isolate 7.2 from alluvial soil grown on Rp medium for about $1.29 \mathrm{x}$ $10^{3} \mu \mathrm{g} \mathrm{mL}^{-1}$ day $^{-1}$. This finding shows that the three isolates showed good activity $(4.2,2.1$ and 2.2$)$, which were from latosol soil. The PSB performance could be tested either through a qualitative or quantitative approach in liquid Pikovskaya media (Selvi et al. 2017). In principle, the PSB could produce phosphatase and certain organic acids (Premono et al. 1966). Phosphatase was a biocatalyst for hydrolysis that could convert from undissolved $\mathrm{P}$ to dissolved P. The phosphate solubilizing microbial will be to improved the efficiency of phosphate fertilizer in soil, organic and inorganic phosphorus, both of which are an important sources for plants to absorb phosphorus in the form of $\mathrm{H}_{2} \mathrm{PO}_{4}{ }^{-}, \mathrm{HPO}_{4}{ }^{2-}$ dan $\mathrm{PO}_{4}{ }^{3-}$ (Kumar et al. 2018).

\section{Nitrogen fixing and phosphate solubilizing bacteria identified}

Homology analysis

PCR amplification of the 16S RNA gene showed that the four bacterial isolates used in this study could be amplified. The resulting amplicon band that looks thick and clear shows this (Figure 1). The resulting PCR products showed sizes between 500-750 bp, according to the target size.

The homology search results of the Latosol 3.1 bacterial isolate sequence on the NCBI database showed similarities to the sequence possessed by the genus Lysinibacillus bacteria (Table 7). The similarity percentage obtained is $99.66 \%$ with the cover query of $98 \%$. The value of the cover query shows what percentage of the length of the nucleotide sequence is in line with the sequence contained in the NCBI database ((https://www.ncbi.nlm.nih.gov/nuccore). The higher the value of the cover query indicates that the analyzed sequence has the same length as the sequence found in the NCBI database. Meanwhile, the value of $E$ is a statistical value that provides an estimate of the significance of the difference between the sequence that is owned and the sequence contained in the database. The higher the $\mathrm{E}$ value indicates that the analyzed sequence has a low level of homology with the sequence found in the NCBI database; conversely, the smaller the $\mathrm{E}$ value (the closer to the number 0), the higher the homology level between the sequence that is owned and the sequence contained in the database.

Table 7. Homology search results of Latosol 3.1 bacterial isolate sequences on the NCBI database

\begin{tabular}{|c|c|c|c|c|}
\hline Sequence description & Name of species & Query cover & $\begin{array}{l}\text { Similarity } \\
\text { percentage }\end{array}$ & $\begin{array}{c}\text { Accession } \\
\text { code }\end{array}$ \\
\hline $\begin{array}{l}\text { Lysinibacillus sp. strain PTVR1 16S ribosomal } \\
\text { RNA gene, partial sequence }\end{array}$ & Lysinibacillus sp. & $98 \%$ & $99.66 \%$ & MK544525.1 \\
\hline $\begin{array}{l}\text { Uncultured Bacillus sp. clone PM- } 81-216 \mathrm{~S} \\
\text { ribosomal RNA gene, partial sequence }\end{array}$ & Uncultured Bacillus sp. & $98 \%$ & $99.66 \%$ & KY225760.1 \\
\hline $\begin{array}{l}\text { Lysinibacillus sp. strain A } 16 \mathrm{~S} \text { ribosomal } \\
\text { RNA gene, partial sequence }\end{array}$ & Lysinibacillus sp. & $98 \%$ & $99.66 \%$ & $\underline{\text { MT912737.1 }}$ \\
\hline $\begin{array}{l}\text { Lysinibacillus fusiformis strain WS1-3 16S } \\
\text { ribosomal RNA gene, partial sequence }\end{array}$ & Lysinibacillus fusiformis & $98 \%$ & $99.66 \%$ & MT605500.1 \\
\hline $\begin{array}{l}\text { Lysinibacillus sp. strain HBUM206408 } 16 \mathrm{~S} \\
\text { ribosomal RNA gene, partial sequence }\end{array}$ & Lysinibacillus sp. & $98 \%$ & $99.66 \%$ & MT541001.1 \\
\hline
\end{tabular}

Table 8. Homology search results of Latosol-4.2 bacterial isolates on the NCBI database

\begin{tabular}{|c|c|c|c|c|}
\hline Sequence description & Name of species & Query cover & $\begin{array}{l}\text { Similarity } \\
\text { percentage }\end{array}$ & $\begin{array}{c}\text { Accession } \\
\text { code }\end{array}$ \\
\hline $\begin{array}{l}\text { Bacillus sp. C-2-6 16S ribosomal RNA } \\
\text { gene, partial sequence }\end{array}$ & Bacillus sp. C-2-6 & $97 \%$ & $99.83 \%$ & KT583455.1 \\
\hline $\begin{array}{l}\text { Lysinibacillus sp. A-2-27 } 16 \mathrm{~S} \text { ribosomal } \\
\text { RNA gene, partial sequence }\end{array}$ & Lysinibacillus sp. A-2-27 & $98 \%$ & $99.66 \%$ & KT583427.1 \\
\hline $\begin{array}{l}\text { Lysinibacillus sp. strain A } 16 \mathrm{~S} \text { ribosomal } \\
\text { RNA gene, partial sequence }\end{array}$ & Lysinibacillus sp. & $98 \%$ & $99.49 \%$ & МТ912737.1 \\
\hline $\begin{array}{l}\text { Lysinibacillus fusiformis strain WS1-3 16S } \\
\text { ribosomal RNA gene, partial sequence }\end{array}$ & Lysinibacillus fusiformis & $98 \%$ & $99.66 \%$ & MT605500.1 \\
\hline $\begin{array}{l}\text { Lysinibacillus sp. strain HBUM } 20640816 \mathrm{~S} \\
\text { ribosomal RNA gene, partial sequence }\end{array}$ & Lysinibacillus sp. & $98 \%$ & $99.66 \%$ & MT541001.1 \\
\hline
\end{tabular}


Table 9. Homology search results of Alluvial -7.1 bacterial isolates on the NCBI database

\begin{tabular}{llccc}
\hline \multicolumn{1}{c}{ Sequence description } & Name of species & Query cover & $\begin{array}{c}\text { Similarity } \\
\text { percentage }\end{array}$ & $\begin{array}{c}\text { Accession } \\
\text { code }\end{array}$ \\
\hline $\begin{array}{l}\text { Fictibacillus sp. strain BacC42 16S ribosomal RNA } \\
\text { gene, partial sequence }\end{array}$ & Fictibacillus sp. & $99 \%$ & $99.83 \%$ & MN128253.1 \\
$\begin{array}{l}\text { Fictibacillus sp. strain C78 16S ribosomal RNA } \\
\text { gene, partial sequence }\end{array}$ & Fictibacillus sp. & $99 \%$ & $99.83 \%$ & MN100172.1 \\
$\begin{array}{l}\text { Fictibacillus sp. strain C58 16S ribosomal RNA } \\
\text { gene, partial sequence }\end{array}$ & Fictibacillus sp. & $99 \%$ & $99.83 \%$ & MN100167.1 \\
$\begin{array}{l}\text { Fictibacillus sp. strain NIORKP269 16S ribosomal } \\
\text { RNA gene, partial sequence }\end{array}$ & Fictibacillus sp. & $99 \%$ & $99.83 \%$ & MH767340.1 \\
$\begin{array}{l}\text { Fictibacillus sp. strain NBS12 16S ribosomal RNA } \\
\text { gene, partial sequence }\end{array}$ & Fictibacillus sp. & $99 \%$ & $99.83 \%$ & MK757936.1 \\
\hline
\end{tabular}

Table 10. Homology search results of alluvial 1.2 bacterial isolates on the NCBI database

\begin{tabular}{|c|c|c|c|c|}
\hline Sequence description & Name of species & Query cover & $\begin{array}{c}\text { Similarity } \\
\text { percentage }\end{array}$ & $\begin{array}{c}\text { Accession } \\
\text { code }\end{array}$ \\
\hline $\begin{array}{l}\text { Bacillus sp. B-3-36 16S ribosomal RNA gene, } \\
\text { partial sequence }\end{array}$ & Bacillus sp. & $99 \%$ & $100 \%$ & KT583529.1 \\
\hline $\begin{array}{l}\text { Bacillus subtilis strain PGPR } 316 \mathrm{~S} \text { ribosomal } \\
\text { RNA gene, partial sequence }\end{array}$ & Bacillus subtilis & $99 \%$ & $100 \%$ & KF578138.1 \\
\hline $\begin{array}{l}\text { Bacillus velezensis strain CIAD-Bm } 16 \mathrm{~S} \text { ribosomal } \\
\text { RNA gene, partial sequence }\end{array}$ & $\begin{array}{l}\text { Bacillus } \\
\text { velezensis }\end{array}$ & $98 \%$ & $100 \%$ & MT218327.1 \\
\hline $\begin{array}{l}\text { Bacillus sp. (in: Bacteria) strain F13 16S ribosomal } \\
\text { RNA gene, partial sequence }\end{array}$ & Bacillus sp. & $99 \%$ & $99.83 \%$ & MH375462.1 \\
\hline $\begin{array}{l}\text { Bacillus subtilis strain SMBL1 16S ribosomal } \\
\text { RNA gene, partial sequence }\end{array}$ & Bacillus subtilis & $98 \%$ & $100 \%$ & MN007187.1 \\
\hline
\end{tabular}

The Latosol 4.2 bacterial isolate showed a similarity to the sequence possessed by the bacteria genus Lysinibacillus (Table 8 ). The similarity percentage obtained ranged from $99.49-99.83 \%$ with a cover query of $97-98 \%$. Meanwhile, the resulting $E$ value of 0 indicates a high homology between the bacterial isolate sequences analyzed using the sequence contained in the NCBI database.

The Alluvial-7.1 bacterial isolate showed a similarity to the sequence possessed by the bacterium Fictibacillus genus (Table 9). The similarity percentage obtained ranged from $99.83 \%$ with a cover query of $99 \%$. Meanwhile, the resulting $\mathrm{E}$ value of 0 indicates a high homology between the bacterial isolate sequences analyzed using the sequence contained in the NCBI database.

The alluvial 1.2 isolate was thought to belong to the genus Bacillus bacteria (Table 10) based on homology analysis. The similarity percentage obtained ranged from $99.83-100 \%$ with a cover query of $98-99 \%$. Meanwhile, the resulting $E$ value of 0 indicates a high homology between the bacterial isolate sequences analyzed using the sequence contained in the NCBI database. The results of the sequence homology of the alluvial-1.2 bacterial isolate showed similarities between Bacillus subtilis and $B$. velezensis with the same level of $100 \%$. However, the query cover in species B. subtilis was greater, e.g. $99 \%$, indicating a high similarity in sequence length between alluvial 1.2 isolates and $B$. subtilis sequence in the database. Thus, in general, two nitrogen-fixing bacterial isolates and two phosphate solvents were identified for their species with high homology.

\section{Phylogeny tree construction}

The results of the phylogeny analysis showed that 4 isolates were compared with the respective bacterial species in the context of the 16S RNA fragment in the NCBI database, showing the presence of a group of bacterial isolates in two distinct groups. Latosol 3-1 and latosol 4.2 isolates were clustered in the same cluster as the genus Lysinibacillus (Figure 2). Meanwhile, Alluvial 1-2 isolates were in a separate sub-cluster with alluvial 7.1. Alluvial 1.2 showed similarities to the genus Bacillus sp., particularly Bacillus subtilis and B. velezensis. Meanwhile, alluvial 7.1 isolates showed high genetic similarity with the genus Fictibacillus. The phylogeny analysis was in accordance with the initial estimates of the species of each bacterial isolate in this study. The results of this molecular analysis still require validation using microscopic morphophysiological data from cultured bacterial colonies, as well as other tests that support microscopically.

The results of the analysis showed that the highest nitrogenase activity isolate was observed in alluvial 6 (1.1 x $\left.10^{9} \mu \mathrm{mol} \mathrm{mL} \mathrm{mours}^{-1}\right)$ and Latosol $4\left(1.7 \times 10^{9} \mu \mathrm{mol} \mathrm{mL}\right.$ ${ }^{1}$ hours $\left.^{-1}\right)$ and highest $\mathrm{P}$ solubilizing activity isolate was latosol 2.2, latosol 3.1 and latosol 2.1 with solubility index (SI) 3.25, 3.22 and 3.00 ( $\mathrm{In} \mathrm{Ca}_{3}\left(\mathrm{PO}_{4}\right)$ media). The isolate high activity of $\mathrm{P}$ solubilizing analysis dissolve was 4.2, 2.1 and $2.2\left(2.88 \times 10^{3} \mu \mathrm{g} \mathrm{mL}^{-1} \mathrm{day}^{-1}, 2.53 \times 10^{3} \mu \mathrm{g} \mathrm{mL}^{-1}\right.$ day $^{-1}$ and $2.43 \times 10^{3} \mu \mathrm{g} \mathrm{mL}^{-1}$ day $^{-1}$ ). 


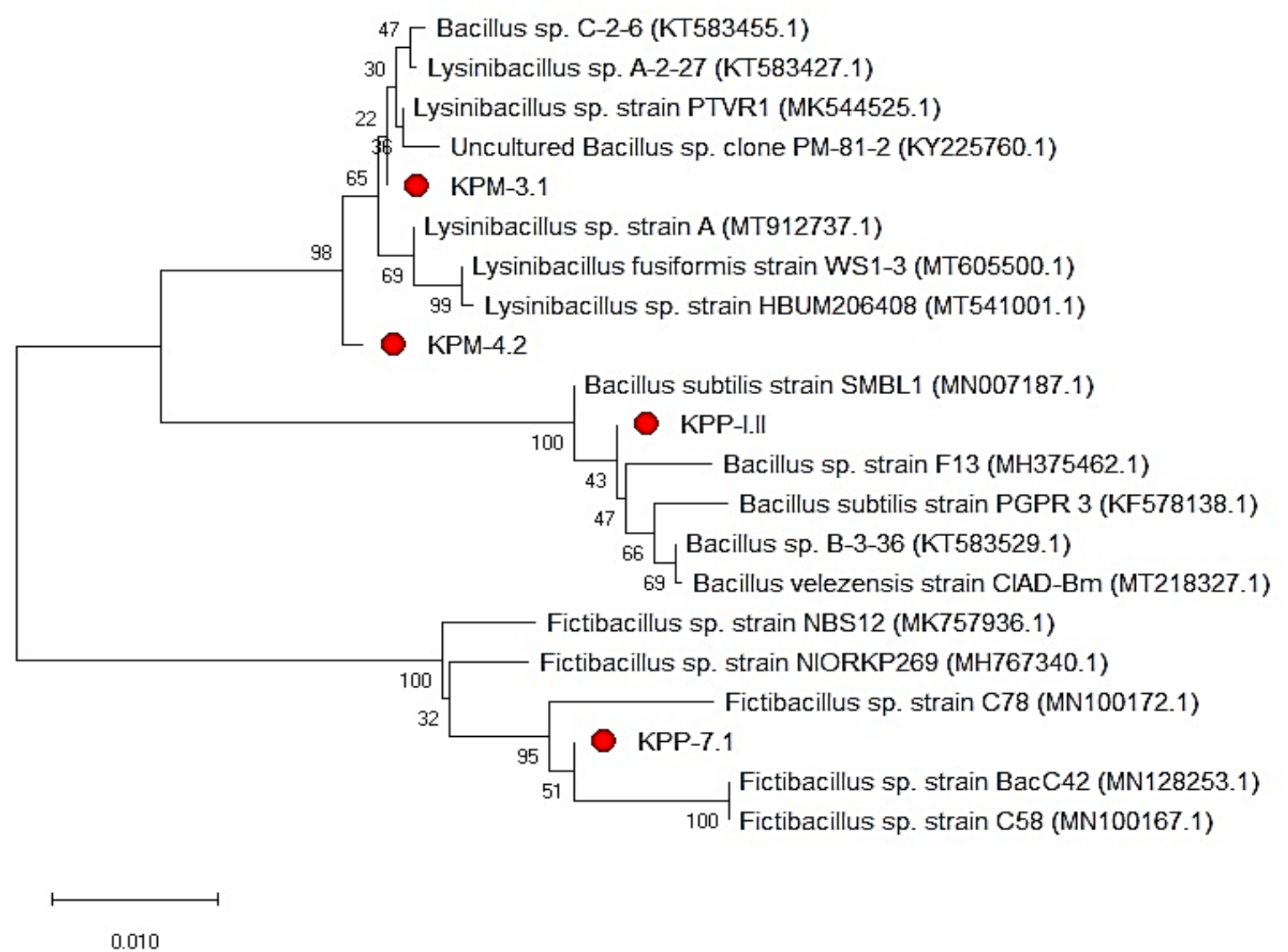

Figure 3. Neighbour-joining phylogenetic tree based on 16S rRNA gene sequences

The phylogeny analyzed showing the presence of bacterial isolates in two distinct groups. Latosol 3.1 and latosol 4.2 isolates were clustered in the same cluster as the genus Lysinibacillus bacteria $(99.66 \%$ with the cover query of $98 \%$ ). Alluvial 7.1 bacterial isolate showed similarities by Fictibacillus sp $(99.83 \%$ with a cover query of $99 \%)$ and alluvial 1.2 isolate showed similarities by the genus Bacillus sp (99.83-100\% with a cover query of 98-99\%.).

It is concluded that bacterial isolated from two type soil paddy fields in the West Java province affected can selected as candidate strains for producing microbiological fertilizer.

\section{ACKNOWLEDGEMENTS}

The authors are very grateful for the Indonesian Center for Food Crops Research and Development, Indonesian Agency for Agricultural Research and Development (IAARD) and Indonesian Soil Research Institute Laboratory, Bogor, Indonesia which supported for providing facilities to conduct this research activity.

\section{REFERENCES}

Alori ET, Glick BR, Babalola OO. 2017. Microbial phosphorus solubilization and its potential for use in sustainable agriculture. Front Microbiol 8: 971. DOI: 10.3389/fmicb.2017.00971

Alfiah LN, Zul D, Nelvia. 2016. Effect of inoculation of Riau mixed phosphate solubilizing bacteria isolate indigenus on growth and production of soybean plants (Glycine $\max$ L. Merr). J Agrotechnol 7 (1): 7-14. DOI: $10.24014 /$ ja.v7i1.2243

Bhattacharyya PN, Jha DK. 2012. Plant growth-promoting rhizobacteria (PGPR): Emergence in agriculture. World J Microbiol Biotechnol 28 (4): 1327-1350. DOI: 10.1007/s11274-011-0979-9

Baig KS, Arshad M, Zahir ZA, Cheema MA. 2010. Comparative efficacy of qualitative and quantitative methods for rock phosphate solubilization with phosphate solubilizing rhizobacteria. Soil Environ 29: 82-86.

Behera BC, Singdevsachan SK, Mishra RR, Dutta SK, Thatoi HN. 2014. Diversity, mechanism and biotechnology of phosphate solubilizing microorganism in mangrove: A review. Biocatalys Agric Biotechnol 3 (2): 97-110. DOI: 10.1016/j.bcab.2013.09.008

BBSDLP. 2020. Hasil Analisis Tanah Laboratorium Tanah. Balai Besar Sumberdaya Lahan Pertanian (BBSDLP), Bogor. [Indonesian]

Bhat TA, Ahmad L, Ganai MA, Ul-Haq S, Khan OA. 2015. Nitrogen fixing biofertilizers: Mechanism and growth promotion: A review. J Pure Appl Microbiol 9: 1675-1690.

Bhardwaj D, Ansari MW, Sahoo RK, Tuteja N. 2014. Biofertilizers function as key player in sustainable agriculture by improving soil fertility, plant tolerance and crop productivity. Microbial Cell Factor 13: 66. DOI: $10.1186 / 1475-2859-13-66$

Cameron KC, Di HJ, Moir JL. 2013. Nitrogen losses from the soil/plant system: A review. Ann Appl Biol 162: 145-173. DOI: 10.1111/aab.12014 
Ding Y, Wang J, Liu Y, Chen S. 2005. Isolation and identification of nitrogenfixing bacilli from plant rhizospheres in Beijing region. $J$ Appl Microbiol 99: 1271-1281. DOI: 10.1111/j.13652672.2005.02738.x

Hartono, Jumadi O. 2014. Seleksi dan karakteristik bakteri penambat nitrogen non simbiotik pengekskresi amonium pada tanah pertanaman jagung (Zea mays L.) dan padi (Oryza sativa L.) asal Kabupaten Barru, Sulawesi Selatan, Indonesia. Jurnal Sainsmat 3 (2): 143-153. DOI: 10.35580/sainsmat3211222014 [Indonesian]

Hawkes C. 2001. Acetylene reduction method for measuring nitrogenase activity tested by Christine Hawkes. Retrieved from http:// ww.biosci.utexas.edu/IB/faculty/hawkes s/lab/protocols/acetylene.

Kesaulya H, Baharuddin, Zakaria B, Syaiful SA. 2015. Isolation and physiological characterization of PGPR from potato plant rhizosphere in medium land of Buru Island. Proc Food Sci 3: 190-199. 10.1016/j.profoo.2015.01.021

Khan MS, Zaidi A, Ahemad M, Oves M, Wani PA. 2010. Plant growth promotion by phosphate solubilizing fungi: Current perspective. Archiv Agronom Soil Sci 56 (1): 73-98. DOI: 10.1080/03650340902806469

Khorso M, Yousef S. 2012. Bacterial biofertilizer for sustainable crop production: A review. J Agric Biol Sci 7 (5): 307-316.

Kumar A, Patel H. 2018. Role of microbes in phosphorus availability and acquisition by plants. Int J Curr Microbiol Appl Sci 7 (5): 1344-1347. DOI: $10.20546 /$ ijcmas.2018.705.161

Ma J, Bei Q, Wang X, Lan P, Liu G, Lin X, Liu Q, Lin Z, Liu B, Zhang Y, Jin H, Hu T, Zhu J, Xie Z. 2019. Impacts of Mo application on biological nitrogen fixation and diazotrophic communities in a flooded rice-soil system. Sci Total Environ 649: 686-694. DOI: 10.1016/j.scitotenv.2018.08.318

Mastur S, Syakir M. 2015. Peran dan pengelolaan hara nitrogenpada tanaman tebu untuk peningkatan produktivitas tebu. Perspektif 14: 73-86. DOI: $10.21082 /$ p.v14n2.2015.73-86 [Indonesian]

Murthi RS, Lisnawita OS. 2015. Potensi bakteri endofit dalam meningkatkan pertumbuhan tanaman tembakau yang terinfeksi nematoda puru akar (Meloidogyne spp.). J Agroekotek 4: 1881-1889. [Indonesian]

Natzke J, Jesse N, José MBB. 2018. Azotobacter vinelandii nitrogenase activity, hydrogen production, and response to oxygen exposure. Appl Environ Microbiol 84 (16): e01208-18. DOI: 10.1128/AEM.01208-18
Paul D, Sinha SN. 2013. Phosphate solubilization potential and phosphatase activity of some bacterial strains isolated thermal power plant effluent exposed water of river Ganga. CIBTech J Microbiol 2 (3): 1-7.

Ranjan A, Mahalakshmi MR, Sridevi M. 2013. Isolation and characterization of phosphate-solubilizing bacterial species from different crop fields of Salem, Tamil Nadu, India. Int J Nutr Pharm Neurolog Dis 3 (1): 29-33. DOI: 10.4103/2231-0738.106982

Sanjotha P, Mahantesh P, Patil CS. 2011. Isolation and screening of efficiency of phosphate solubilizing microbes. Int J Microbiol Res 3: 56-58. DOI: 10.9735/0975-5276.3.1.56-58

Sane SA, Mehta SK. 2015. Isolation and evaluation of rock phosphate solubilizing fungi as potential bio-fertilizer. J Fertil Pestic 6: 2. DOI: $10.4172 / 2471-2728.1000156$

Selvi KB, Paul J, Vijaya V, Saraswathi K. 2017. Analyzing the efficacy of phosphate solubilizing microorganisms by enrichment culture techniques. Biochem Mol Biol J 3: 1. DOI: 10.21767/24718084.100029

Sharma SB, Sayyed RZ, Trivedi MH, Gobi TA. 2013. Phosphate solubizing microbes: Sustainable approach for managing phosphorus deficiency in agricultural soils. Springer Plus 2: 587. DOI: 10.1186/2193-1801-2-587

Situmorang EC, Prameswara ASHC, Mathius NT, Liwan T. 2015. Indigenous phospate solubilizing bacteria from peat soil for an ecofriendly biofertilizer in oil palm plantation. Renewable Energy and Energy Conversion Conference and Exhibition 1: 65-72. DOI: 10.18502/ken.v1i1.324

Sukristiyonubowo, Ritung S, Nugroho K. 2012. Nitrogen and potassium balance of newly opened wetland rice field. J Agr Sci Soil Sci 2: 207216.

Youssef MMA, Eissa MFM. 2014. Biofertilizers and their role in management of plant parasitic nematodes: A review. J Biotechnol Pharm Res 5: 1-6.

Yu X, Liu X, Zhu TH, Liu GH, Mao C. 2011. Isolation and characterization of phosphate solubilizing bacteria from walnut and their effect on growth and phosphorus mobilization. Biol Fertil Soils 47: 437-446. DOI: 10.1007/s00374-011-0548-2 